DOI https://doi.org/10.18551/rjoas.2017-11.49

\title{
THE STORAGE EFFECT ON SALAK SUWARU POLLEN VIABILITY
}

\author{
Sudaryono Tri, Researcher \\ Assessment Institute for Agricultural Technology, East Java, Indonesia \\ E-mail: tri sdr@yahoo.com
}

\begin{abstract}
Salak is a cross-pollinated plant, where the presence of pollen is required for pollination and fertilization process. The availability of Salak pollen is very fluctuating, at times pollen is excessively available, and otherwise at certain times the pollen is unavailable. Such circumstance affects the production of Salak Suwaru. The solution in pollen tentative availability is required in order to achieve the continuity of Salak Suwaru's production. Research about pollen storage is expected to achieve practical result as the solution of Salak Suwaru pollen tentative availability. The purpose of this research is to identify the effect of storage method on the viability of Salak Suwaru pollen has been done from May to July 2017. The result shows that the storage method influenced Salak Suwaru pollen viability. The viability of Salak Suwaru pollen stored in freezer up to 8 weeks is adequately high; it is more than $70 \%$. The Salak Suwaru pollen storage in freezer can be used to overcome the pollen's unavailability at certain times.
\end{abstract}

\section{KEY WORDS}

Pollen, freezer, exicator, viability.

In Indonesia, Salak is one of the fruit clusters considered to have a competitive advantage prioritized in the fruit development program, in which expected to be able to play an important role in regional economic development (Directorate General of Horticultural Production and Various Plants, 2001). One of the superior Salak developed in East Java is Salak Suwaru which comes from Malang Regency. Salak Suwaru as one of East Java's superior fruit has been released as a superior variety through Ministry of Agriculture Decree No: 120 / Kpts / TP / 240/3/1991. The superiorities of Salak Suwaru are thick meat, ripe, sweet, sharp-flavored and weight per fruit is between 70-120 g (Widyastuti and Paimin, 1993).

Salak (Salacca edulis Reinw) syn Salaccazalacca (Gaertner) Voss (Schuiling and Mogea, 1992) belongs to the growing family of Palmae. Based on sex, Salak included in dioecious plants, male and female flowers are in different plants (Mogea, 1978). On the basis of the nature of such flowers, Salak plants are generally cross-pollinated (Frankel and Galun, 1977; Fisher and Mogea, 1980). Based on the cross-pollination nature of Salak plants, the presence of male Salak as a source of pollen is very important.

Naturally, Salak sprouts appear every $2-3$ months along with the emergence of new sprout (Purnomo, 1993). According to this fact Salak harvest season should not be only twice as occurred currently. In line with the flowers arise periodicity; harvest should be obtained in the off-season which can occur in March - May or August - October.

The absence of off-season harvests is caused by many factors, in particular at certain times female Salak plants do not produce flowers or the presence of male Salak plants as a source of pollen and the availability of non-continuous pollen (Sudaryono, et al., 1999).

The availability of non-continuous pollen indicates that at certain times there are female Salak flowers that are plummetingdue to non-pollination. A possible approach to overcome pollen incontinence is the preservation or storage of pollen. Therefore, it is required to find the appropriate storage method of Salak Suwaru pollen.

The aim of this research is to identify the effect of storage method on the pollen viability and to acquire the proper way of storing Salak Suwaru's pollen. 


\section{METHODS OF RESEARCH}

The study was conducted from May to July 2013 at the Plant Breeding and Culture Breeding Laboratory, Agricultural Technology Assessment Institute of East Java, Malang. The research material is Salak Suwaru male pollen. The study was conducted using a completely randomized design with the treatment of storing pollen, which is stored in an exicator at room temperature, and stored in a freezer. Freezers are used as a way of storing pollen with the consideration that every farm household has a refrigerator equipped with a freezer. Pollen collecting procedure is according to Akihima and Omuru method (1986) and Shivanna and Rangaswamy (1992).

The viability of pollen observation was at 1 -week intervals. The pollen viability test was conducted using in vitro media according to Hengki and Gaghaube (1999). The growing media of each Petridis is made of $0.3 \mathrm{~g}$ gelatin, $375 \mathrm{~g}$ sucrose or sugar, $3 \mathrm{mg}$ boric acid and $25 \mathrm{ml}$ of distilled water. The ingredients are heated in a beaker glass until boiling, and then poured into Petridis with 2-2.5 mm thickness evenly. After the media is cold (about 5 minutes), the pollen is sown evenly onto the surface of the media with the help of a small quartz, then left for two hours and the pollen viability is observed under a microscope. The calculation of pollen viability is by dividing the media into five parts of the area. In each field is observed 1 time, therefore the number of observations in a Petridis are 5 times. The level of pollen viability in each field by using the formula as follows:

$$
\text { Pollen Viability }=\frac{\sum \text { germinated pollen in the relevant plane }}{\sum \text { pollen that is observed in the relevant field }} \times 100 \%
$$

\section{RESULTS AND DISCUSSION}

SalakSuwaru pollen viability observation was conducted during 1 to 8 weeks storage, along with 1 week interval observation. Based on the formula, pollen viability is a comparison between the amount of germinated pollen which is characterized by the formation of pollen tube (Figure 1) with the amount of observed pollen which is the accumulation from nongerminated pollen (Figure 2) and germinated pollen.

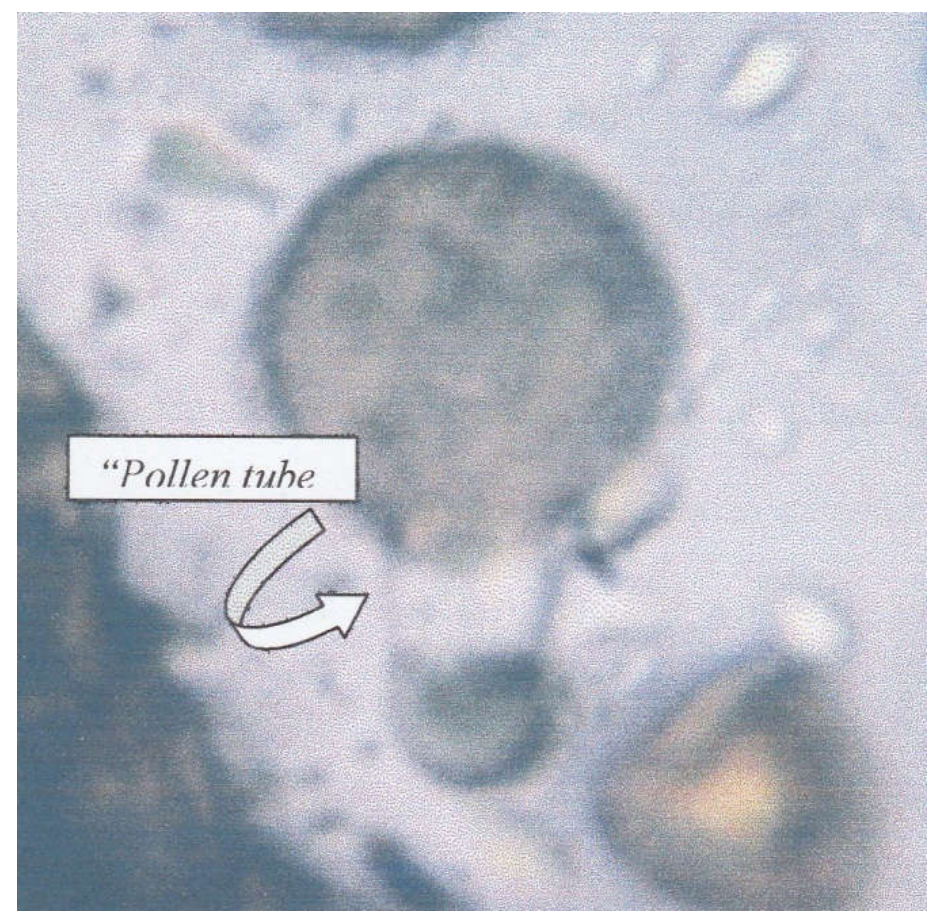

Figure 1 - Germinated Salak pollen which is characterized by the formation of pollen tube 


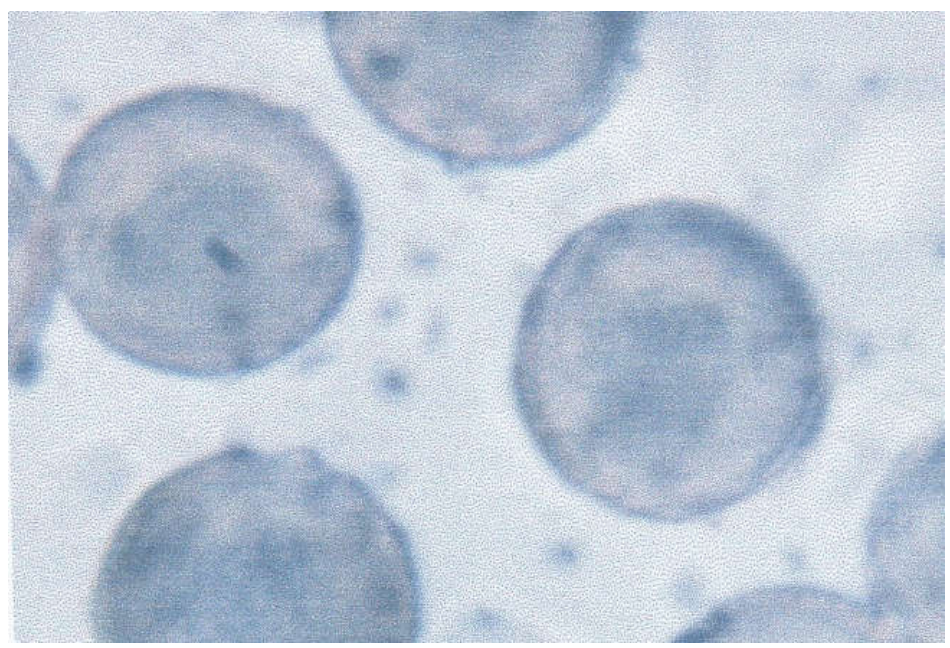

Figure 2 - Non-germinated Salak pollen which is characterized by the non-formation of pollen tube

Statistical analysis indicates that the storage method influenced the viability of Salak pollen. SalakSuwaru pollen stored in the freezer decreased their viability more gradually than those stored in the exicator (Figure 3).

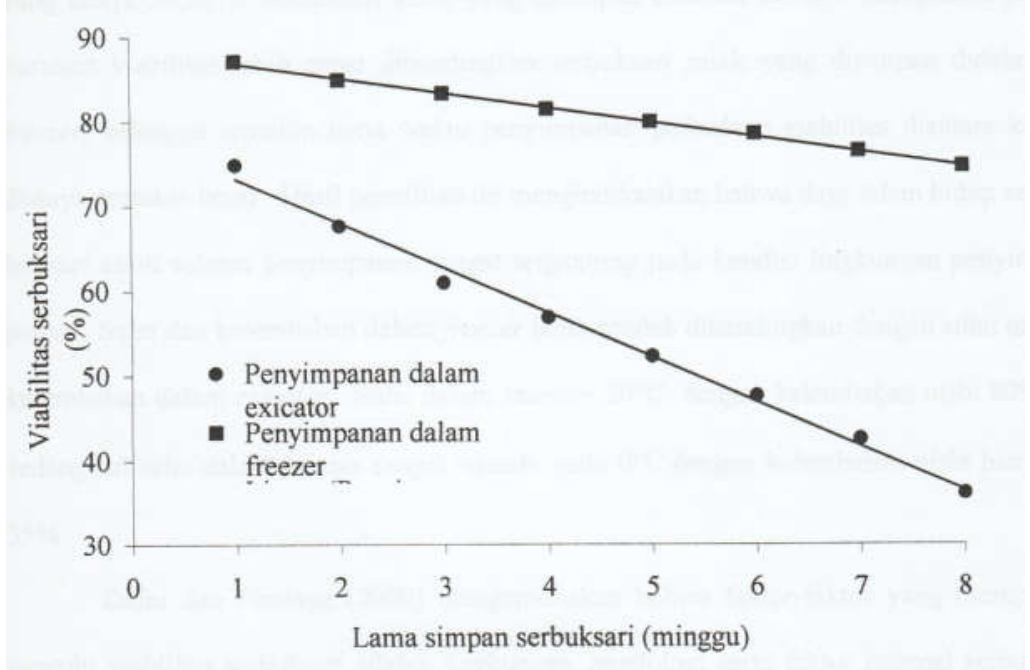

Figure 3 - The relationship between the old save with the viability of Salak Suwaru pollen stored in the exicator and freezer

In Figure 3 it shows that during 1 to 8 weeks storage, Salak Suwaru pollen stored in the freezer always shows higher viability compared to pollen's viability stored in the exicator. At 8 weeks storage, Salak Suwaru pollen viability stored in the freezer is still adequately high; it is about $74.59 \%$ two times greater than Salak Suwaru pollen viability stored in the exicator which is only $36.02 \%$. Based on these observations, Salak Suwaru pollen stored in the freezer for 8 weeks can still be used in pollination. Hengki and Gaghaube (1999) from the results of their research on coconut plants suggested that pollen which has sprouts strength above $40 \%$ can still be used as pollination material.

Salak Suwaru pollen stored in the exicator has faster viability decrease than Salak Suwaru pollen stored in the freezer, therefore the longer the storage time, the greater difference between the viability of both. The results of this study indicate that the survival rate of Salak Suwaru pollen during storage is highly dependent on the environmental of storage conditions. The temperature and humidity in the freezer are lower than the temperature and humidity inside the exicator. The temperature inside the exicator is about $30^{\circ} \mathrm{C}$ with $80 \%$ relative humidity, whereas the temperature inside the freezer is very low, it is $0^{\circ} \mathrm{C}$ with only $35 \%$ relative humidity. Dafni and Firmage (2000) stated that the affecting factors of pollen 
viability are the environment, morphology and the internal pollen itself. The main environmental factors affecting the life-sustenance of pollen are moisture and temperature (Akihima and Omura, 1986; Dafni and Firmage, 2000). The temperature influence on pollen viability has been proven by Pool and Bermawie (1986). Storage of clove pollen for 48 weeks in the temperature range $-20^{\circ} \mathrm{C}$ to $-25^{\circ} \mathrm{C}$ can maintain $2.2 \%$ pollen viability. While the moisture influence on pollen viability can be perceived in this study's results. Up to 8 weeksstorage, the viability of Salak Suwaru pollen stored in the exicator reaches only half of the pollen viability stored in the freezer. This relates to the existing moisture in the exicator and freezer. The humidity in the exicator is twice bigger compared to the humidity in the freezer. Stanley and Linskens (1974) stated that pollen survival during storage is generally negatively correlated with relative humidity. Furthermore, it is argued that the best life of pollen is achieved in the relative humidity of $6-60 \%$.

The results of this study can be used by Salak Suwaru farmers to provide pollen throughout the season. When the male Salak flowers are plentiful, pollen is collected and inserted into small clear glass bottles. Furthermore, bottles containing the pollen are stored in the freezer inside the refrigerator. This method can easily be done by farmers, assumed that almost every farmer's house has a refrigerator. In this way, the farmers of Salak Suwaru will get the certainty of pollen availability throughout the seasons.

\section{CONCLUSION}

The storage method influences Salak Suwaru pollen viability. Salak Suwaru pollen stored in the freezer up to 8 weeks viability is still adequately high, that is more than $70 \%$. Storage of Salak Suwaru pollen in the freezer can be used to overcome pollen unavailability at certain times.

\section{REFERENCES}

1. Akihima, T. and M. Omuru. 1986. Preservation of fruit tree pollen. P. $101-112$. In: Y. P. S. Bajaj (ed.). Biotechnology in agriculture and forestry. Vol. I Springer-Verlag.

2. Dafni, A. 2000. Pollen viability and longevity: practical, ecological and evolutionary implications. p. 113 - 132. In: Dafni, A. (ed.). pollen and pollination. Springer.

3. Directorate General of Horticulture Production and Multifarious Plants. 2001. Hortikultura dan Aneka Tanaman. Memerlukan kontinuitas suplai sesuai selera konsumen. Agribisnis Indonesia. P. 8 -11.

4. Fisher, J. B. and J. P. Mogea. 1980. Intrapetialar inflorescence buds in Salacca (Palmae): development and significance. Bot. J. Linnear Soc. 81: $47-59$.

5. Frankel, R. and E. Galun. 1977. Pollination mechanism reproduction and plant breeding. Springer-Verlag Berlin Heidlberg New York.

6. Hengki, N. dan K. Gaghaube. 1 999. Teknik prosesing dan keragaman hasil polen dari beberapa kultivar kelapa dalam. Buletin Plasma Nutfah 5(1): $16-23$.

7. Mogea, J. P. 1978. Pollination in Salacca edulis. Principes 22 (2): $56-63$.

8. Pool, P. A. and N. Bermawie. 1986. Pollen storage in clove (Syzygium aromatic (L.) Merr and Perr. Indonesian J. Crop Sci. 2(2): 53 - 58.

9. Purnomo, S. 1993. Biologi bunga dan pembungaan salak (Salacca edulis Reinw). Sub Balai Penelitian Hortikultura, Malang.

10. Schuiling, D. L. 1992. Salacca zalacca (Gaertner) Voss. p. $281-284$. In: Verheij, E. W. (ed.). Plant resources of South East 2: Edible Fruit and nuts. Pudoc/Prosea.

11. Shivanna, R. 1992. Pollen biology. A laboratory manual. Springer-Verlag.

12. Stanley, R. G. and H. F. Linskens. 1974. Pollen: biology biochesmitry management. Springer-Verlag Berlin Heidelberg, New York.

13. Sudaryono, T. 1999. Perakitan Teknologi peningkatan frekuensi panen salak unggulan Jawa Timur. p. 122-128.

14. Widyastuti, Y. E. dan F. R. Paimin. 1983. Mengenal buah unggul Indonesia. PT Penebar Swadaya, Jakarta. 